\title{
Analisa Dan Perbandingan Sistem Aplikasi Diagnosa Penyakit Asma Dengan Algoritma Certainty Factor Dan Algoritma Decision Tree Berbasis Android
}

\author{
Niki Ratama*) \\ Jurusan Teknik Informatika, Fakultas Teknik, Universitas Pamulang, Tangerang Selatan \\ Jln. Surya Kencana No. 1, Pamulang - Tangerang Selatan, 15417, Indonesia \\ email: nickyratama@gmail.com \\ Received: 23 Maret 2018; Revised: 9 Mei 2018; Accepted: 13 Mei 2018 \\ Copyright $(02018$ Politeknik Harapan Bersama Tegal. All rights reserved
}

\begin{abstract}
A computer is a tool that become the needs of society, both in the society in general, educational institutions, industry and even in the world of health, in the issue of health scope using technology, there are several cases that can be implemented, one of which is knowledge. Knowledge is a science that a person has acquired where the knowledge takes a long time to get it, sometimes someone with knowledge needs to store that knowledge, there are many methods in storing knowledge, from noting to books, videos and even giving it to someone else, but the method takes a long time, the expert system can be one solution in the knowledge where the expert system is a system that can be incorporated knowledge and store knowledge in the system, there are many expert system methods such as expert system method using Certainty Factor algorithm and algorithm Decision Tree. In the problem taken is to analyze, where asthma disease is the five largest disease that causes death in the world that varies between 6-30\% (around 16.5\%). In making the system using the waterfall model procedure and the program created using web display for admin management and display android device for user interface, the purpose of which is done in this research is with the application of expert systems \& artificial intelligence, users or community will be knowing way and first handling in overcoming the asthma disease where the implementation of applications based on android smartphone, which can be used anywhere.
\end{abstract}

Abstrak - Komputer adalah suatu alat teknologi yang menjadi kebutuhan masyarakat, baik dilingkungan masyarakat pada umumnya, lembaga pendidikan, perindustrian dan bahkan didunia kesehatan, dalam permasalahan diruanglingkup kesehatan yang menggunakan teknologi terdapat beberapa kasus yang bisa diimplementasikan, salah satunya adalah pengetahuan. Pengetahuan adalah suatu ilmu yang telah didapat seseorang dimana pengetahuan tersebut membutuhkan waktu yang cukup lama untuk mendapatkannya, terkadang seseorang yang mempunyai pengetahuan perlu untuk menyimpan pengetahuan tersebut, terdapat banyak metode dalam penyimpanan pengetahuan, dari mencatat kedalam buku, video bahkan memberikannya kepada seseorang yang lainnya, tetapi cara tersebut membutuhkan waktu yang lama, sistem pakar bisa menjadi salah satu solusi dalam pengetahuan dimana sistem

*) Corresponding author: Niki Ratama

Email: nickyratama@gmail.com pakar adalah suatu sistem yang bisa dimasukkan pengetahuan dan menyimpan pengetahuan didalam sistem, terdapat banyak metode sistem pakar diantaranya adalah metode sistem pakar dengan menggunakan algoritma Certainty Factor dan algoritma Decision Tree. Dalam permasalahan yang diambil adalah menganalisa, dimana penyakit asma adalah penyakit lima terbesar yang menyebabkan kematian didunia yang bervariasi antara $6-30 \%$ (berkisar 16,5\%). Dalam pembuatan sistem menggunakan prosedur model waterfall dan program yang dibuat menggunakan tampilan web untuk pengelolaan admin dan tampilan android device untuk interface user, tujuan dari yang dilakukan dalam penelitian ini adalah dengan adanya aplikasi sistem pakar \& artificial intellegence tersebut, pengguna atau masyarakat akan mengetahui cara dan penanganan terlebih dahulu dalam mengatasi penyakit asma tersebut dimana implementasi aplikasi berbasis smartphone android, yang dapat digunakan dimana saja.

Kata Kunci - Knowledge Base, Penyakit Asma, Diagnosa, Sistem Pakar, Certainty Factor, Decision Tree, Expert System.

\section{PENDAHULUAN}

Pemakaian dan penggunaan komputer saat ini sudah mempengaruhi hampir diseluruh aspek kehidupan dan hampir digunakan dalam bidang seluruh pekerjaan yang menggunakan sistem computer [1], dimana sistem komputer tersebut dapat membantu seseorang dalam menyelesaikan masalahnya atau pekerjaannya [2], termasuk juga dalam bidang kesehatan [3]. Banyak masalah kesehatan yang dapat diterapkan dalam sistem pakar [4][5], terutama adalah penyakit asma pada manusia.

Penyakit asma adalah suatu kelainan yang terjadi dan mengakibatkan inflamasi (peradangan) kronik pada saluran pernafasan yang mengakibatkan hiperaktivitas bronkus pada rangsangan dengan gejala berupa adanya suara mengi, dan disertakan timbul batuk dimana mengalami perasaan sesuatu yang berat pada dada terutama waktu malam hari [6], dan juga mengalami sesak pada saluran pernafasan. Pada umumnya penyakit asma yang diderita memiliki sifat fluctuative [7] (hilang timbul) dimana memiliki arti dapat bersifat tenang tanpa adanya sesuatu gejala tetapi juga dapat dirasakan eksaserbasi dengan gejala ringan atau gejala berat dan juga dapat memberikan dampak kematian [8]. 
Penyakit asma mengatagorikan suatu penyakit berat dan termasuk penyakit lima terbesar yang menyebabkan kematian[9] didunia yang antara 6-30\% (berkisar 16,5\%). Banyak solusi yang dapat menyelesaikan dan menyembuhkan penyakit asma, salah satunya adalah dengan mendatangi kedokter atau seorang pakar kesehatan[10], seorang pakar dalam menyelesaikan masalah pada umumnya dengan mengandalkan pengetahuan yang dimiliki atau membuka buku-buku pengetahuan tentang bidang masalah tersebut [11]. Tidak selamanya seorang dokter atau pakar kesehatan dapat dengan cepat mendiagnosa suatu penyakit [12] pada manusia terutama penyakit asma. Untuk menjadi seorang dokter atau pakar kesehatan dibutuhkannya waktu dan biaya pendidikan serta pengalaman menghadapi masalah yang cukup lama [13], pada keadaan tertentu seorang pakar atau dokter juga dapat saja mengalami kesehatan yang kurang baik atau mengalami sakit bahkan sangat disayangkan apabila seorang pakar kesehatan tersebut meninggal dunia.

Berdasarkan permasalahan diatas, dibutuhkan suatu sistem yang dapat membantu dalam bidang diagnosa dalam menentukan penyakit asma dan penanganannya, ada banyak metode atau algoritma sistem pakar yang dapat diimplementasikan diantaranya adalah adalah algoritma Certainty Factor dan algoritma Decision Tree, pada penelitian sebelumnya yang dilakukan Widians membahas deteksi atau mendiagnosa penyakit asma yang terjadi pada anak dengan menerapkan metode sistem pakar algoritma Certainty Factor dan penelitian yang dilakukan oleh Rachmawat dengan topik permasalahan adalah diagnosa penyakit asma dengan metode forward chaining, kedua penelitian tersebut membahas topik kesehatan yaitu tentang penyakit asma, yang dibedakan hanyalah penggunaan metodenya, kasus analisa dan perbandingan sistem aplikasi diagnosa penyakit asma dengan menggunakan algoritma certainty factor dan algoritma decision tree berbasis android merujuk dari penelitian sebelumnya. dengan adanya aplikasi sistem pakar \& artificial intellegence tersebut, pengguna atau masyarakat akan mengatahui cara dan penanganan terlebih dahulu dalam mengatasi penyakit asma tersebut dimana implementasi aplikasi berbasis smartphone android, yang dapat digunakan dimana saja.

\section{PENELITIAN YANG TERKAIT}

Dalam penelitian ini, peneliti menggunakan beberapa penelitian lain yang berhubungan sebagai berikut, penelitian yang dilakukan oleh Zarandi, F [14], yang berjudul " $a$ fuzzy rule-based expert system for diagnosing asthma" membahas tentang menganalisa penyakit asma dengan membuat diagnosa dari gejala-gejala yang terjadi pada penyakit asma dengan menggunakan logika fuzzy inference system, Tujuan penelitian ini adalah untuk merancang expert system berbasis aturan fuzzy untuk mengurangi bahaya ini dengan mendiagnosis asma pada tahap awal. Representasi pengetahuan dari sistem ini disediakan dari tingkat tinggi, berdasarkan pada persepsi pasien, dan disusun dalam dua struktur yang berbeda disebut Tipe A dan Tipe B. Tipe A terdiri dari enam modul, termasuk gejala, rinitis alergi, faktor genetik, gejala hiper-responsif, faktor medis dan faktor lingkungan. Tipe $\mathrm{B}$ adalah terdiri dari 8 modul termasuk gejala, rinitis alergi, faktor genetik, respons terhadap obat jangka pendek menggunakan, tes bronkodilator, tes tantangan, tes PEF dan oksida nitrat yang dihembuskan. Hasil akhir dari setiap sistem adalah de-fuzzied untuk memberikan penilaian kemungkinan asma untuk pasien. Kriteria klasifikasi dan validasi yang dipertimbangkan, sistem digunakan oleh beberapa partisipasi dokter umum, dokter asma yang berpengalaman dan pasien penderita asma.

Penelitian yang dilakukan oleh Rachmawati, dkk penelitian yang dilakukan dengan judul, "aplikasi sistem pakar diagnosis penyakit asma" [15] membahas tentang penyakit asma yang dialami oleh manusia dan membuat aplikasi diagnosa penyakit asma dengan menggunakan algoritma forward chaining dan model perancangan untuk membuat aplikasinya menggunakan model perancangan ESDLC atau Expert System Development Life Cycle, Penelitian ini menghasilkan sebuah rancang bangun sistem aplikasi diagnosa penyakit asma dengan menerapkan algoritma forward Chaining.

Selanjutnya penelitian yang dilakukan oleh Angelina, Joan W \& Hidayati, I pada tahun 2016 , dengan judul penelitiannya "sistem pendiagnosa penyakit asma pada anak dengan metode certainty factor"'[16], pada penelitian ini membahas seberapa pentingnya menjaga dan berbahayanya penyakit asma yang terjadi pada anak, dengan membuat sistem aplikasi diagnosa menggunakan metode Certainty Factor sebagai solusinya sehingga menjadikan solusi untuk penanganan dalam pemberian informasi, yang dibangun kedalam sistem aplikasi.

Berdasarkan tiga penelitian sebelumnya, yang membahas metode sistem pakar terhadap diagnosa seputar kesehatan, maka dalam penelitian ini membahas tentang terkaitnya yang berdasarkan jurnal sebelumnya, yaitu tentang sistem pakar yang mengambil permasalahan seputar kesehatan (penyakit asma) dengan menggunakan perhitungan dan logika dari algoritma Certainty Factor dan algoritma Decision Tree serta menganalisa kedua algoritma tersebut dalam perhitungan juga logika dan hasil output, pengujian yang dilakukan untuk mengukur tingkat nilai presentasi aplikasi dari kedua algoritma tersebut menggunakan pengujian nilai koesioner berdasarkan katagori dan hasil nilai fakta, sistem aplikasi diagnosa penyakit asma yang dibangun ini diharapkan dapat memberikan fasilitas untuk digunakan oleh tenaga kesehatan didalam pemberian sebuah pengantar informasi kesehatan kepada warga atau masyarakat umum untuk melakukan deteksi dini dan seberapa pentingnya menjaga kesehatan dari gejala penyakit asma, dan masyarakat dapat menggunakan dengan mudah untuk mengetahui gejala atau penyakit asma yang disertakan penanganan berupa kesimpulan pencegahan atau cara penanganan untuk pengobatan penderita penyakit asma yang dapat dipergunakan langsung dan kapan saja dengan menggunakan fasilitas interface mobile android.

\section{A. Proses Akuisisi Pengetahuan}

Berdasarkan dari sumber-sumber penelitian dan referensi yang sudah disampaikan sebelumnya, maka proses berikutnya akan diklasifikasikan berdasarkan beberapa nama penyakit pada penyakit asma yang dapat disusun untuk dimasukkan kedalam sebuah sistem yang ada pada Tabel I. Selanjutnya data gejala-gejala yang pada umumnya timbul pada penderita, data gejala ini kemudian disusun dan dapat dilihat pada tabel II. Tahapan selanjutnya adalah penyusunan data solusi pengobatan, sesuai pada tabel III. 
TABEL I

DATA JENIS PENYAKIT ASMA

\begin{tabular}{|c|c|}
\hline $\begin{array}{c}\text { KODE } \\
\text { PENYAKIT }\end{array}$ & NAMA PENYAKIT \\
\hline P01 & Acute Asthma \\
\hline P02 & Chronic Asthma \\
\hline P03 & Periodic asthma \\
\hline P04 & Extrinsic Asthma \\
\hline P05 & Asthma Intrinsic \\
\hline P06 & Asthma Weight \\
\hline P07 & Asthma Medium \\
\hline P08 & Mild Asthma \\
\hline P09 & Occupational Asthma \\
\hline P10 & Aspirin-Sensitive Asthma \\
\hline P11 & Sports-induced asthma \\
\hline
\end{tabular}

TABEL II

DATA JENIS PENYAKIT ASMA

\begin{tabular}{|c|c|}
\hline Kode Gejala & Nama Gejala \\
\hline G01 & $\begin{array}{l}\text { Sesak pada napas yang terjadi secara tiba- } \\
\text { tiba }\end{array}$ \\
\hline G02 & $\begin{array}{l}\text { Mengalami intensitas sesak berat pada } \\
\text { pernapasan }\end{array}$ \\
\hline G03 & Adanya bunyi pada napas berupa (mengi) \\
\hline G04 & Mengalami batuk \\
\hline G05 & Dada terasa berat \\
\hline G06 & Mengalami perasaan gelisah \\
\hline G07 & $\begin{array}{l}\text { Sering Terjadi Sesak Nafas (Kambuh } \\
\text { Priodik) }\end{array}$ \\
\hline G08 & $\begin{array}{l}\text { Mengalami meningkatnya sesak nafas } \\
\text { pada pernapasan yang terasa ringan dan } \\
\text { bisa berat }\end{array}$ \\
\hline G09 & Terkadang adanya bunyi napas (mengi) \\
\hline G10 & Terkadang adanya batuk \\
\hline G11 & $\begin{array}{l}\text { Sesak napas dikarnakan adanya sebuah } \\
\text { alergi }\end{array}$ \\
\hline G12 & $\begin{array}{l}\text { Rasa tidak enak dan terjadi gatal pada } \\
\text { bagian tubuh atau badan }\end{array}$ \\
\hline G13 & Mengalami flu dan bersin \\
\hline G14 & Adanya atau terjadi pilek \\
\hline G15 & Mengalami hidung tersumbat \\
\hline G16 & $\begin{array}{l}\text { Terjadi sesak napas yang tidak enak dan } \\
\text { terasa berat }\end{array}$ \\
\hline G17 & $\begin{array}{lll}\begin{array}{l}\text { Mempunyai gejala peradangan atau } \\
\text { infection }\end{array} & & \\
\end{array}$ \\
\hline G18 & $\begin{array}{l}\text { Sesak nafas yang sangat tidak nyaman } \\
\text { pada saat beristirahat atau sedang tenang }\end{array}$ \\
\hline G19 & Pernapasan berbunyi nyaring \\
\hline G20 & $\begin{array}{l}\text { Mengalami otot pada bagian dada yang } \\
\text { terasa tidak nyaman atau sakit }\end{array}$ \\
\hline G21 & $\begin{array}{l}\text { Ada pernapasan tidak nyaman pada } \\
\text { bagian hidung }\end{array}$ \\
\hline $\mathrm{G} 22$ & $\begin{array}{l}\text { Mengalami intensitas pada pernapasan } \\
\text { yang increased }\end{array}$ \\
\hline G23 & $\begin{array}{l}\text { Mengalami sedikit sesak nafas pada } \\
\text { waktu berkata }\end{array}$ \\
\hline G24 & $\begin{array}{l}\text { Terkadang terjadi rasa tidak enak pada } \\
\text { pernafasan disaat menggerakan bagian } \\
\text { tubuh atau otot }\end{array}$ \\
\hline
\end{tabular}

\begin{tabular}{|c|l|}
\hline G25 & $\begin{array}{l}\text { Mengalami sesak yang tidak terlalu } \\
\text { (Ringan), disaat berbicara atau sedang } \\
\text { melakukan gerakan jalan }\end{array}$ \\
\hline G26 & $\begin{array}{l}\text { Mengalami alergi ditempat-tempat } \\
\text { tertentu atau tempat aktifitas }\end{array}$ \\
\hline G27 & $\begin{array}{l}\text { Bersin-bersin yang dialami pada suatu } \\
\text { tempat keseharian dimana lebih banyak } \\
\text { tempat aktifitas }\end{array}$ \\
\hline G28 & $\begin{array}{l}\text { Hidung mengalami rasa tidak enak } \\
\text { desertakan adanya lendir }\end{array}$ \\
\hline G29 & $\begin{array}{l}\text { Mengalami rasa tidak enak dan tambah } \\
\text { memburuk disaat menggunakan aspirin }\end{array}$ \\
\hline G30 & $\begin{array}{l}\text { Otot-otot disekitar saluran pernapasan } \\
\text { berkontraksi }\end{array}$ \\
\hline G31 & $\begin{array}{l}\text { Terjadi kondisi yang memburuk selama } \\
\text { dan setelah melakukan olahraga }\end{array}$ \\
\hline G32 & Mengalami pernapasan cepat dan dangkal \\
\hline
\end{tabular}

TABEL III

DATA JENIS PENYAKIT ASMA

\begin{tabular}{|c|c|}
\hline Kode Solusi & Nama Penyakit \\
\hline S01 & $\begin{array}{l}\text { Gunakanlah obat penyakit asma berupa } \\
\text { inhaler (uap), menggunakan uap nebu } \\
\text { (nebulizer) atau berupa obat asma yang } \\
\text { disuntikan }\end{array}$ \\
\hline S02 & $\begin{array}{l}\text { Kurangi aktifitas yang menjadikan } \\
\text { kambuhnya penyakit asma/serangan asma, } \\
\text { dan segeralah menggunakan obat asma } \\
\text { (meminum obat), disaat terjadinya asma, } \\
\text { dan pada saat melakukan aktifitas seperti } \\
\text { bermain atau olahraga, sebaiknya jangan } \\
\text { terlalu intent atau aktif (jaga stamina atau } \\
\text { nafas pada saat berolahraga atau main) }\end{array}$ \\
\hline S03 & $\begin{array}{l}\text { Kurangi aktifitas yang menyebabkan } \\
\text { terjadinya asma, dan segera menggunakan } \\
\text { obat asma (meminum obat) jika } \\
\text { kambuhnya penyakit asma, hilangkan } \\
\text { beban pikiran karna akan menimbulkan } \\
\text { stress yang akan mengakibatkan tubuh } \\
\text { menjadi lelah dan berdampak kembuhnya } \\
\text { penyakit asma }\end{array}$ \\
\hline S04 & $\begin{array}{l}\text { Kurangi aktifitas yang menyinggung } \\
\text { tempat-tempat yang tidak sehat (berdebu), } \\
\text { atau berbulu dan kotor, hindari makanan } \\
\text { yang mengakibatkan terjadinya alegri, dan } \\
\text { dapat memberikan alergen (jangan } \\
\text { berlebih), gunakanlah pakaian yang bersih } \\
\text { dan sering-seringlah menghirup udara pagi } \\
\text { yang segar }\end{array}$ \\
\hline S05 & $\begin{array}{l}\text { Gunakanlah obat asma, segeralah } \\
\text { meminum obat asma bila terjadi asma pada } \\
\text { pernafasan, dan bisa juga dibantu dengan } \\
\text { obat infeksi seperti antibiotik }\end{array}$ \\
\hline S06 & $\begin{array}{l}\text { Gunakanlah obat penyakit asma berupa uap } \\
\text { (nebulizer), cairan yang dapat berubah uap, } \\
\text { bisa juga menggunakan obat sama yang } \\
\text { disuntikkan (konsultasi kedokter untuk } \\
\text { dosis) }\end{array}$ \\
\hline S07 & $\begin{array}{l}\text { Gunakanlah obat penyakit asma dengan } \\
\text { memberikan cairan uap berupa nebulizer, }\end{array}$ \\
\hline
\end{tabular}




\begin{tabular}{|c|l|}
\hline & $\begin{array}{l}\text { juga bisa menggunakan tabung oksigen bila } \\
\text { mengalami intensitas yang terus menerus, } \\
\text { bisa juga menggunakan obat yang } \\
\text { disuntikan (obat oral) }\end{array}$ \\
\hline S08 & $\begin{array}{l}\text { Gunakan cairan uap (nebulizer), atau } \\
\text { berikan oksigen pada pernapasan dengan } \\
\text { menggunakan tabung oksigen }\end{array}$ \\
\hline S09 & $\begin{array}{l}\text { Lakukan aktivitas yang berbeda den sehat, } \\
\text { atau berpindahlah tempat aktifitas atau } \\
\text { tempat kerja yang sebelumnya dapat } \\
\text { mengakibatkan terjadinya alergi }\end{array}$ \\
\hline S10 & $\begin{array}{l}\text { Bisa menggunakan beberapa obat asma, } \\
\text { atau menggunakan obat singulair } \\
\text { disertakan obat antagonis reseptor, untuk } \\
\text { menangani leukotrin untuk meningkatkan } \\
\text { kondisi tubuh dan dapat melakukan } \\
\text { aktifitas atau kerja secara normal }\end{array}$ \\
\hline S11 & $\begin{array}{l}\text { Kurangi beberapa aktifitas yang aktif dan } \\
\text { berat, dan kurangi olahraga yang intent } \\
\text { untuk menjaga stamina, datanglah kedokter } \\
\text { atau pakar kesehatan asma untuk } \\
\text { berkonsultasi seputar penyakit asma yang } \\
\text { terjadidan penanganannya }\end{array}$ \\
\hline
\end{tabular}

Nilai CF/ factor kebenaran didapatkan dari interpretasi term seorang pakar[17], untuk mendapatkan nilai MD dan nilai MB tertentu. Nilai keyakinan atau ketidakyakinan yang digunakan untuk menghitung nilai kombinasi CF dari MD dan MB pada suatu rule[18], dapat dilihat pada Tabel IV.

\section{B. Implementasi Decision Tree}

Berdasarkan data penyakit dan gejala untuk rule berdasarkan bentuk atau algoritma Decision Tree pada deteksi penyakit asma, maka diklasifikasi data gejala sesuai penyakitnya, ditemukan data sebagai berikut :

- Penyakit Asma Akut gangguan yang terjadi pada kode gejala antara lain : G01, G02, G03, G04, G05 dan G06.

- Penyakit Asma Kronis gangguan yang terjadi pada kode gejala antara lain : G07, G08, G09 dan G10.

- Penyakit Asma Periodik gangguan yang terjadi pada kode gejala antara lain : G06, G10, dan G07.

- Penyakit Asma Ekstrinsik gangguan yang terjadi pada kode gejala antara lain: G11, G12, G13, G14, dan, G15.

- Penyakit Asma Intrinsik gangguan yang terjadi pada kode gejala antara lain : G04, G16, dan G17.

- 6 Penyakit Asma Berat gangguan yang terjadi pada kode gejala antara lain : G18, G19, G20, G21, dan G22.

- Penyakit Asma Sedang gangguan yang terjadi pada kode gejala antara lain : G22, G23, G03, dan G24.

- Penyakit Asma Ringan gangguan yang terjadi pada kode gejala antara lain : G22, G25, dan G03.

- Penyakit Asma Pekerjaan gangguan yang terjadi pada kode gejala antara lain : G26, G27, G28, dan G15.

- Penyakit Asma Sensitif Aspirin gangguan yang terjadi pada kode gejala antara lain : G03, G29, dan G30.

- Penyakit Asma yang dipicu Olahraga gangguan yang terjadi pada kode gejala antara lain : G03, G31, dan G32.

Dari data gangguan yang terjadi dan data penyakit, juga gangguan maka selanjutnya dibentuk aturan Decision Treenya, seperti Gbr.1.

TABEL IV

DATA JENIS PENYAKIT ASMA

\begin{tabular}{|l|c|}
\hline \multicolumn{1}{|c|}{ Certain Term } & MB / MD \\
\hline Tidak Mengetahui & $0-0.29$ \\
\hline Kemungkinan Terjadi & $0.3-0.49$ \\
\hline Kemungkinan Terjadi besar & $0.5-0.69$ \\
\hline Hampir Bisa Dipastikan & $0.7-0.89$ \\
\hline Sangat Bisa Dipastikan & $0.9-1.0$ \\
\hline
\end{tabular}

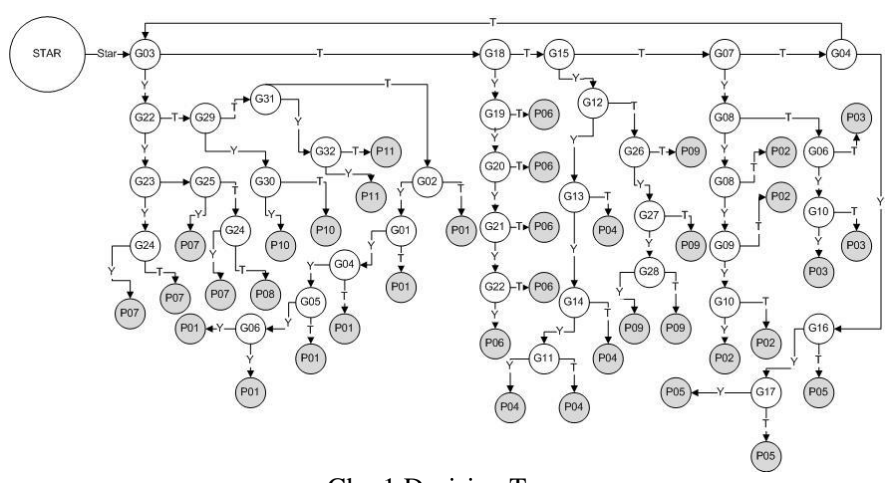

Gbr. 1 Decision Tree

TABEL V

Pengujian Koesioner Nilai Presentase Tampilan

\begin{tabular}{|l|l|l|l|l|l|l|l|l|l|}
\hline Katagori & $\begin{array}{l}\text { Sangat } \\
\text { Baik }\end{array}$ & Baik & $\begin{array}{l}\text { Cukup } \\
\text { Baik }\end{array}$ & $\begin{array}{l}\text { Biasa } \\
\text { Saja }\end{array}$ & $\begin{array}{l}\text { Kurang } \\
\text { Baik }\end{array}$ & $\begin{array}{l}\text { Tidak } \\
\text { Baik }\end{array}$ & $\begin{array}{l}\text { Sangat } \\
\text { Tidak } \\
\text { Baik }\end{array}$ & $\begin{array}{l}\text { Jumlah } \\
\text { Pertanyaan }\end{array}$ \\
\hline $\begin{array}{l}\text { Pertenyaan } \\
\text { Ke2 }\end{array}$ & 2 & 3 & 5 & 0 & 0 & 0 & 0 & 10 \\
\hline $\begin{array}{l}\text { Pertenyaan } \\
\text { Ke4 }\end{array}$ & 3 & 3 & 4 & 0 & 0 & 0 & 0 & 10 \\
\hline $\begin{array}{l}\text { Pertenyaan } \\
\text { Ke9 }\end{array}$ & 4 & 2 & 2 & 2 & 0 & 0 & 0 & 10 \\
\hline KTotalKatagori & 9 & 8 & 11 & 2 & 0 & 0 & 0 & 30 \\
\hline Presentasi & $30 \%$ & $26,67 \%$ & $36,67 \%$ & $6,67 \%$ & $0 \%$ & $0 \%$ & $0 \%$ & $100 \%$ \\
\hline
\end{tabular}

\section{HASIL DAN PEMBAHASAN}

Implementasi penerapan setelah dilakukan metode penelitian selesai, yang selanjutnya diimplementasikan kedalam bahasa pemrograman yang dibangun menggunakan model rancang bangun waterfall, tujuan dari implementasi ini bertujuan untuk memberikan sebuah konfirmasi dari modul program yang nantinya digunakan oleh beberapa aktor atau user pengguna dalam penggunaannya, hasil dari penelitian menghasilkan sistem aplikasi/ Expert System untuk diagnosa gejala yang terjadi pada penyakit asma dan menentukan jenis penyakit asma dengan menerapkan algoritma certainity factoty dan forward chaining (Decision Tree) berbasis android dan nilai presentase aplikasi diuji menggunakan uji nilai presentase berdasarkan koesioner berdasarkan katagori.

Uji nilai presentase dilakukan pada interface setiap algoritma yang sudah dibangun dan dapat dilihat berdasarkan Tabel V dan Tabel VI untuk pengujian algoritma certainity factor. 
TABELVI

PENGUJIAN KOESIONER NILAI PRESENTASE EFEKTIFITAS

\begin{tabular}{|l|l|l|l|l|l|l|l|l|}
\hline Katagori & $\begin{array}{l}\text { Sangat } \\
\text { Efektif }\end{array}$ & Efektif & $\begin{array}{l}\text { Cukup } \\
\text { Efektif }\end{array}$ & $\begin{array}{l}\text { Biasa } \\
\text { Saja }\end{array}$ & $\begin{array}{l}\text { Kurang } \\
\text { Efektif }\end{array}$ & $\begin{array}{l}\text { Tidak } \\
\text { Efektif }\end{array}$ & $\begin{array}{l}\text { Sangat } \\
\text { Tidak } \\
\text { Efektif }\end{array}$ & $\begin{array}{l}\text { Jumlah } \\
\text { Pertanyaan }\end{array}$ \\
\hline $\begin{array}{l}\text { Pertanyaan } \\
\text { Ke1 }\end{array}$ & 4 & 3 & 1 & 2 & 0 & 0 & 0 & 10 \\
\hline $\begin{array}{l}\text { Pertanyaan } \\
\text { Ke3 }\end{array}$ & 2 & 3 & 4 & 1 & 0 & 0 & 0 & 10 \\
\hline $\begin{array}{l}\text { Pertanyaan } \\
\text { Ke5 }\end{array}$ & 4 & 2 & 4 & 0 & 0 & 0 & 0 & 10 \\
\hline $\begin{array}{l}\text { Pertanyaan } \\
\text { Ke6 }\end{array}$ & 3 & 3 & 2 & 2 & 0 & 0 & 0 & 10 \\
\hline $\begin{array}{l}\text { Pertanyaan } \\
\text { Ke7 }\end{array}$ & 4 & 4 & 2 & 0 & 0 & 0 & 0 & 10 \\
\hline $\begin{array}{l}\text { Pertanyaan } \\
\text { Ke8 }\end{array}$ & 1 & 2 & 3 & 4 & 0 & 0 & 0 & 10 \\
\hline $\begin{array}{l}\text { Pertanyaan } \\
\text { Ke10 }\end{array}$ & 6 & 2 & 2 & 0 & 0 & 0 & 0 & 10 \\
\hline \begin{tabular}{l} 
LTotalKatagori \\
\hline Presentasi
\end{tabular} & 24 & 19 & 18 & 9 & 0 & 0 & 0 & 70 \\
\hline
\end{tabular}

TABELVII

PENGUJIAN KOESIONER NILAI PRESENTASE TAMPILAN

\begin{tabular}{|l|l|l|l|l|l|l|l|l|}
\hline Katagori & $\begin{array}{l}\text { Sangat } \\
\text { Baik }\end{array}$ & Baik & $\begin{array}{l}\text { Cukup } \\
\text { Baik }\end{array}$ & $\begin{array}{l}\text { Biasa } \\
\text { Saja }\end{array}$ & $\begin{array}{l}\text { Kurang } \\
\text { Baik }\end{array}$ & $\begin{array}{l}\text { Tidak } \\
\text { Baik }\end{array}$ & $\begin{array}{l}\text { Sangat } \\
\text { Tidak } \\
\text { Baik }\end{array}$ & $\begin{array}{l}\text { Jumlah } \\
\text { Pertanyaan }\end{array}$ \\
\hline $\begin{array}{l}\text { Pertenyaan } \\
\text { Ke2 }\end{array}$ & 2 & 2 & 4 & 2 & 0 & 0 & 0 & 10 \\
\hline $\begin{array}{l}\text { Pertenyaan } \\
\text { Ke4 }\end{array}$ & 2 & 3 & 5 & 0 & 0 & 0 & 0 & 10 \\
\hline $\begin{array}{l}\text { Pertenyaan } \\
\text { Ke9 }\end{array}$ & 2 & 2 & 2 & 4 & 0 & 0 & 0 & 10 \\
\hline KTotalKatagori & 6 & 7 & 11 & 6 & 0 & 0 & 0 & 30 \\
\hline Presentasi & $20 \%$ & $23,33 \%$ & $36,67 \%$ & $20 \%$ & $0 \%$ & $0 \%$ & $0 \%$ & $100 \%$ \\
\hline
\end{tabular}

TABELVIII

PENGUJIAN KOESIONER NILAI PRESENTASE EFEKTIFITAS

\begin{tabular}{|l|l|l|l|l|l|l|l|l|}
\hline Katagori & $\begin{array}{l}\text { Sangat } \\
\text { Efektif }\end{array}$ & Efektif & $\begin{array}{l}\text { Cukup } \\
\text { Efektif }\end{array}$ & $\begin{array}{l}\text { Biasa } \\
\text { Saja }\end{array}$ & $\begin{array}{l}\text { Kurang } \\
\text { Efektif }\end{array}$ & $\begin{array}{l}\text { Tidak } \\
\text { Efektif }\end{array}$ & $\begin{array}{l}\text { Sangat } \\
\text { Tidak } \\
\text { Efektif }\end{array}$ & $\begin{array}{l}\text { Jumlah } \\
\text { Pertanyaan }\end{array}$ \\
\hline $\begin{array}{l}\text { Pertanyaan } \\
\text { Ke1 }\end{array}$ & 2 & 3 & 2 & 3 & 0 & 0 & 0 & 10 \\
\hline $\begin{array}{l}\text { Pertanyaan } \\
\text { Ke3 }\end{array}$ & 2 & 1 & 4 & 3 & 0 & 0 & 0 & 10 \\
\hline $\begin{array}{l}\text { Pertanyaan } \\
\text { Ke5 }\end{array}$ & 3 & 3 & 3 & 1 & 0 & 0 & 0 & 10 \\
\hline $\begin{array}{l}\text { Pertanyaan } \\
\text { Ke6 }\end{array}$ & 2 & 2 & 3 & 3 & 0 & 0 & 0 & 10 \\
\hline $\begin{array}{l}\text { Pertanyaan } \\
\text { Ke? }\end{array}$ & 4 & 2 & 2 & 2 & 0 & 0 & 0 & 10 \\
\hline $\begin{array}{l}\text { Pertanyaan } \\
\text { Ke8 }\end{array}$ & 1 & 3 & 3 & 3 & 0 & 0 & 0 & 10 \\
\hline $\begin{array}{l}\text { Pertanyaan } \\
\text { Ke10 }\end{array}$ & 3 & 2 & 4 & 1 & 0 & 0 & 0 & 10 \\
\hline \begin{tabular}{l} 
KTotalKatagori \\
\hline Presentasi
\end{tabular} & $24,28 \%$ & $22,85 \%$ & $30 \%$ & $22,85 \%$ & $0 \%$ & $0 \%$ & $0 \%$ & 70 \\
\hline
\end{tabular}

Uji nilai presentase selanjutnya dilakukan untuk interface algoritma Decision Tree, dan dapat dilihat pada Tabel VII dan Tabel VIII. Selanjutnya dapat dilihat tampilan pada tahap installasi dan tampilan login pada tampilan android device pada Gbr. 2. Tampilan instalasi dan tampilan login aplikasi pada Gbr. 2, dimana aplikasi diagnosa harus menggunakan akun email yang sudah terdaftar terlebih dahulu didatabase admin.

Tampilan halaman utama dan halaman home pada Gbr. 3, menjelaskan aplikasi interface user untuk pengguna android, terdapat 2 menu diagnosa, certainity factoty dan forward chaining (Decision Tree). Tampilan halaman login admin pada Gbr. 4, untuk mengelola data pengetahuan pada aplikasi diagnosa.

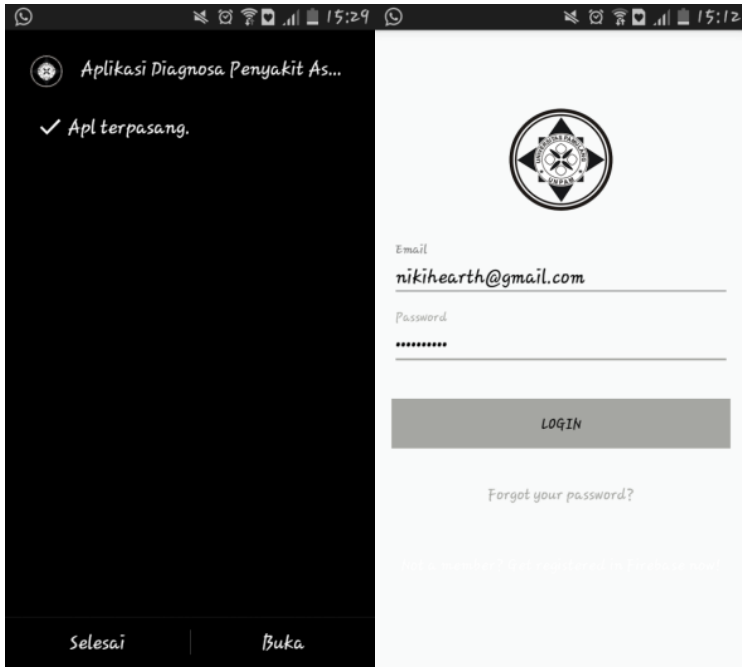

Gbr. 2 Tampilan Instalasi Dan Login Aplikasi

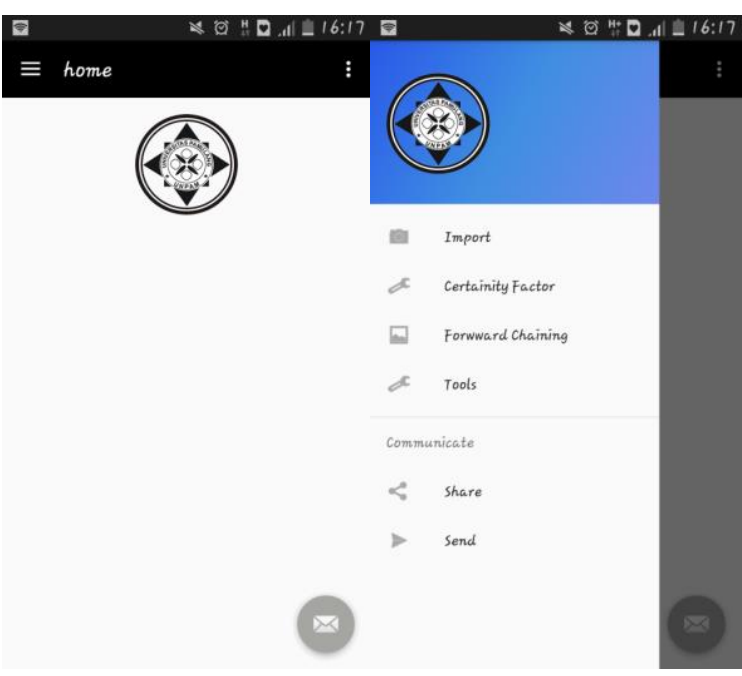

Gbr. 3 Tampilan Halaman Utama Dan Menu Utama

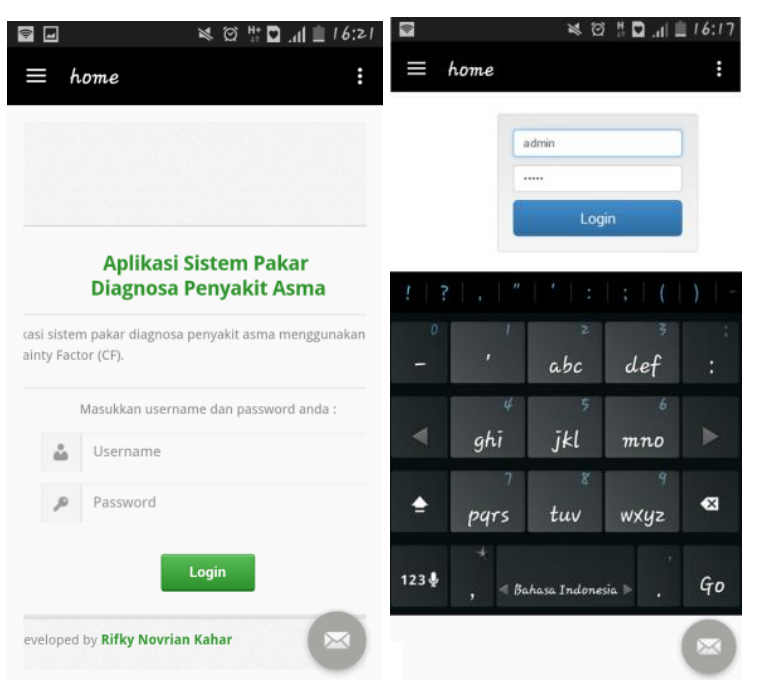

Gbr. 4 Tampilan Halaman Login Cf Dan Fc 


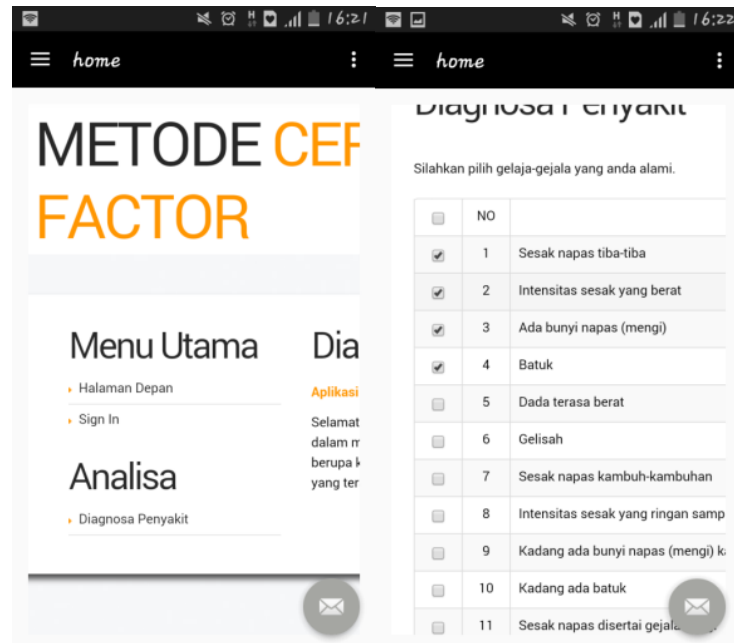

Gbr. 5 Tampilan Diagnosa Certainty Factor

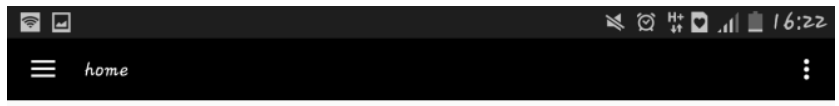

LAPORAN HASIL DIAGNOSA



Gbr. 6 Tampilan Laporan Diagnosa

Tampilan Diagnosa algoritma Certainty Factor pada Gbr. 5, memberikan tampilan untuk diagnosa yang menampilkan beberapa gejala, dimana user atau pengguna hanya tinggal memberikan ceklist pada gejala yang dialaminya. Tampilan Laporan Diagnosa pada Gbr. 6, memberikan hasil akhir berupa data diagnosa, disertakan nilai tingkat keyakinan yang dipresentasikan kedalam nilai persentase, dan hasil laporan juga memberikan pencegahan atau penanganan lanjut yang berupa solusi untuk pengguna dalam penyakit asma yang dikatagorikan.

\section{KESIMPULAN}

Untuk mendiagnosa penyakit asma dengan menerapkan metode sistem pakar dengan mengimplementasikan algoritma Certainty Factor dan Decision Tree, dimana algoritma tersebut dianalisa dan dibandingkan dengan data study kasus dan pengambilan nilai presentasi berdasarkan koesioner pengguna berdasarkan sampel yang sudah dibagikan, aplikasi ini dibangun telah efektif dalam menentukan jenis penyakit asma, dimana memiliki nilai presentasi efektifitas sebanyak $34,28 \%$ menyatakan sangat efektif, yang diambil berdasarkan 7 parameter dan untuk algoritma Decision Tree sebanyak $30 \%$ cukup efektif, algoritma Certainty Factor lebih memiliki keakuratan yang baik dengan presentasi $100 \%$ dibandingkan dengan menggunakan algoritma Decision Tree dengan presentasi 50\%, dimana algoritma Certainty Factor memiliki nilai kepastian yang diberikan seorang pakar atau dokter, sedangkan algoritma Decision Tree tidak memiliki kepastian, metode tersebut hanya memiliki rule yang berupa kondisi percabangan berupa implikasi.

Kedua algoritma masih memerlukan data berupa pengetahuan yang didapat dari seorang pakar, sehingga akan menjadi keterbatasan sistem pada jenis penyakit yang belum dimasukkan nama penyakitnya dan nilai dari rule algoritmanya, dan sistem yang dibangun menggunakan prosedur model waterfall dalam perancangan sistemnya, dan dibangun tampilan web di kedua algoritma tersebut dimana admin yang mengelola aplikasi webnya dan dibangun juga android interfacenya. Interface android bertujuan untuk memudahkan pengguna dalam menggunakan aplikasi sistem pakar untuk diagnosa penyakit asma.

\section{UCAPAN TERIMA KASIH}

Dengan kerendahan hati dan keterbatasan peneliti sepenuhnya memberikan ucapan terima kasih kepada beberapa pihak yang telah membantu ataupun memberikan dukungan terkait dengan penelitian yang dilakukan seperti bantuan fasilitas penelitian, dana hibah, dan lainnya.

\section{DAFTAR PUSTAKA}

[1] C. M. Faculty, M. Altan, B. Öner, and M. A. Körpinar, "Comparative Study on Computer / Internet Use and Knowledge Skills of the New Entrants and Current Students in the," vol. 4, no. 2, pp. 167-171, 2013.

[2] C. Technology, "Quantity and quality of computer use and academic achievement: Evidence from a large-scale international test program Jehanzeb R . Cheema University of Illinois at Urbana-Champaign , USA Bo Zhang," Int. J. Educ. Dev. using Inf. Commun. Tecnol., vol. 9, no. 2, pp. 95-106, 2013.

[3] A. Shanthasheela and E. Nithya, "International Journal of Computer Engineering and Applications , A Study Of Bone Fracture Detection Algorithms," vol. XII, no. I, pp. 473-478.

[4] M. S. Josephine and V. Jeyabalaraja, "Expert System and Knowledge Management for Software Developer in Software Companies," vol. 2, no. 3, pp. 243-247, 2012.

[5] L. Sudarmana and F. Lestari, "Aplikasi Sistem Pakar Untuk mendiagnosis Gangguan Jiwa Schizophrenia,” vol. 3, no. 1, pp. 40-44, 2018 .

[6] T. Syafiuddin, U. Zein, D. Pangestuti, S. A. Lubis, K. Kontributor, and P. Medan, "Buku Panduan Kerja Modul Kepaniteraan Klinik Ilmu Penyakit Paru," 2017.

[7] B. Prasadl, P. E. S. N. K. Prasad, and Y. Sagar, "A N A Pproach To D Evelop E Xpert S Ystems In M Edical Diagnosis Using M Achine L Earning A Lgorithms ( A Sthma ) And A P Erformance S Tudy," vol. 2, no. 1, pp. 26-33, 2011.

[8] "The Pediatric Asthma Intervention : A Comprehensive Cost-Effective Approach to Asthma Management in a Disadvantaged," no. 768512181.

[9] Z. Kabir, P. J. Manning, J. Holohan, and P. G. Goodman, "Prevalence of Symptoms of Severe Asthma and Allergies in Irish School Children : An ISAAC Protocol Study , 1995 - 2007," vol. 1995, pp. 3192-3201, 2011.

[10] P. S. K. Patra, "An Expert System for Diagnosis of Human Diseases," Int. J. Comput. Appl., vol. 1, no. 13, pp. 71-73, 2010.

[11] J. Dada, H. Kochs, and J. Petersen, "Web-Based Expert System for Classification of Industrial and Commercial Waste Products," $J$. Emerg. Trends Comput. ..., vol. 2, no. 6, pp. 257-262, 2011.

[12] A. Oluwafemi and J. Ibrahim, "Expert System for Diagnosis Neurodegenerative Diseases," Int. J. Comput. Inf. Technol., vol. 4, no. 4, pp. 2279-764, 2015.

[13] C. F. Tan, L. S. Wahidin, S. N. Khalil, N. Tamaldin, J. Hu, and G. W. M. Rauterberg, "the Application of Expert System: a Review of Research,” vol. 11, no. 4, pp. 2448-2453, 2016.

[14] M. H. F. Zarandi, M. Zolnoori, M. Moin, and H. Heidarnejad, "A Fuzzy Rule-Based Expert System for Diagnosing Asthma," Sci. Iran. Trans. E-Industrial Eng., vol. 17, no. 2, pp. 129-142, 2010 
[15] A. S. Rachmawati, D. Johar Damiri, “Aplikasi Sistem Pakar Diagnosis Penyakit Asma,” J. Ilm. Tek. Inf., no. Sistem Pakar, pp. 1-7, 2009.

[16] I. H. Joan Angelina Widians, "Sistem Pendiagnosa Penyakit Asma Pada Anak Dengan Metode Certainty Factor," no. sistem pakar, pp. 67, 2016.
[17] Y. Sarlati and S. Jafari, "Implementation of Expert System for Lending With Certainty Factor," vol. 3, no. 4, pp. 33-37, 2014.

[18] B. Ambara, D. Putra, and D. Rusjayanthi, "Fuzzy Expert System of Dental and Oral Disease with Certainty Factor," vol. 14, no. 3, pp. 22 30, 2017. 